\title{
Statyba
}

\section{GENERATION OF THE UNSTRUCTURED FE-GRIDS FOR COMPLEX 2D OBJECTS}

\section{E. Stupak MSc \& R. Baušys}

To cite this article: E. Stupak MSc \& R. Baušys (2000) GENERATION OF THE UNSTRUCTURED FE-GRIDS FOR COMPLEX 2D OBJECTS, Statyba, 6:1, 17-24, DOI: $10.1080 / 13921525.2000 .10531559$

To link to this article: https://doi.org/10.1080/13921525.2000.10531559

曲 Published online: 26 Jul 2012.

Submit your article to this journal

III Article views: 40 


\section{NESTRUKTŪRINIŲ BE TINKLŲ GENERAVIMAS SUDE்TINGIEMS DVIMAČIAMS OBJEKTAMS}

\section{E. Stupak, R. Baušys}

\section{Ivadas}

Pastaruoju metu baigtiniu elementų metodu (BEM) sprendžiama daugelis inžinerijos sričių problemų. Dèl universalumo šis metodas tapo modeliavimo pagrindu daugeliui kompiuterinio projektavimo paketu.

Tačiau vienas iš BEM trükumų yra tas, kad analizès tikslumas labai priklauso nuo BE tinklo kokybès. Jeigu inžinerinių struktūrų su dideliais aproksimuojamuju parametru gradientais diskretizacija netobula, tai skirtumas tarp skaitinių ir realiuju sprendinių gali būti žymus. Siekiant kontroliuoti analizès kokybę, gali būti taikomos ivairios klaidu ìvertinimo procedūros. Pastaruoju metu konstrukcijoms modeliuoti naudojami nestruktūriniai $\mathrm{BE}$ tinklai. Nestruktūrinis BE tinklas - tai toks tinklas, kuriame elementu̧, supančiu vidini mazga skaixius kinta mus dominančios srities viduje. Šių tinklų kūrimas yra automatizuotas, taikant vadinamąsias adaptyviąsias strategijas [1-8]. Tinklu prisitaikymo procesas yra iteracinis. Visu pirma yra sudaromas pradinis tinklas, gaunamas pirmasis sprendinys ir procesas tęsiamas tol, kol yra gaunamas reikiamas tikslumas. Taciau, norint sèkmingai ir efektyviai panaudoti šias adaptyviąsias strategijas, svarbu turèti pakankamai kokybiskką pradini BE tinklą, kuriame yra ivertinta konstrukcijos geometrija, apkrovos bei medžiagos pasiskirstymo ypatumai.

Pasaulinèje inžinerijoje yra paplitę ivairūs adaptyviujų baigtinių elementų tinklu generavimo metodai [1]. Pirmają klasę sudaro plintancio fronto metodai. Antraja klasę - vadinamieji Voronojaus arba Delaunay trianguliacijos metodai. Ju pagrindinis algoritmo žingsnis yra tinkamas nauju taškų iterpimas i BE tinklą. Šie metodai yra taikomi tik trikampių ir tetraedrinių elementų BE tinklams sukurti. Nors visi క̌ie metodai vienas nuo kito gerokai skiriasi, tačiau visiems jiems bendra yra tai, kad tinklas turi turèti galimybę būti pritaikomas tam tikrai problemai spręsti. Inžinerijoje కie metodai vis labiau po- puliareja, nes sprendžiant daugelị inžinerinių problemų reikia, kad tinklas būtų tankesnis tik tam tikrose būdingose vietose, o kitur pakaktų ir retesnio. Plintancio fronto metodas yra plačiai taikomas plokštiems ir erdviniams nestruktūriniams tinklams generuoti [1-9]. Sis metodas pradètas taikyti pirmiausia geometriniams kraštams kaip briaunu rinkinio dviem kryptimis diskretizacija [5].

Plokšiu ir erdviniu BE tinklų generavimo lygiagrečiaisiais procesoriais, taikant plintančio fronto technika, srityje yra daug nuveike prof. B. H. V. Toppingas ir jo kolegos $[8,10,11]$ iš Heriot-Watt Universiteto (Edinburgas, Jungtinè Karalystè).

Tradicinès adaptyviuju BE tinklu generavimo strategijos paprastai pradedamos nuo palyginti reto ir tolygaus tankumo tinklo. Atliekant sudètingu inžineriniu sistemų analizę, reikia atlikti nemažai iteracijų tol, kol sukuriamas optimalus BE tinklas, kuriame aproksimacijos paklaida yra mažesnè už leistiną ir yra tolygiai pasiskirsciusi visame inžinerinès sistemos modelyje.

Šio darbo tikslas yra generuoti pradinị nestruktūrinių baigtinių elementų tinklą, kuriame ivertinami inžinerinio objekto ypatumai. Šis tikslas igyvendinamas taikant ekspertinę sistemą.

Sukurtoje ekspertineje sistemoje panaudojama pradinė informacija apie objekto geometrija, kraštines ir apkrovimo sąlygas, medžiagos pasiskirstyma. Šios informacijos pagrindu generuojamas pradinis nestruktūrinis $\mathrm{BE}$ tinklas, kuriame yra ivertinti konkrečios inžinerinès sistemos ypatumai. Taip jau pirmuoju iteraciniu žingsniu sukuriamas beveik optimalus BE tinklas.

Buvo atlikta keletas skaitiniu eksperimentu, taikant pasiūlytą ekspertinę sistema, generuojant BE tinklus sudètingos struktūros sritims. Ekspertinè sistema leidžia generuoti skirtingus pradinius $\mathrm{BE}$ tinklus priklausomai nuo pradinès informacijos apie inžinerinę sistema. Šiuose eksperimentuose buvo vertinamas tiktai skirtingu medžiagų sąlytis bei skirtingos apkrovimo salygos. 


\section{Adaptyviųjų BE tinklų generavimo pagrindiniai principai}

Šiame skyriuje pateikiame pagrindinius tinklų generavimo procedūros principus, kuriais remiantis sukurta ekspertinè sistema. Trumpai apibūdinsime pagrindines idejas:

1. Hierarchinis generavimo principas. Tai reiškia, kad tinklus generuojant mazgai ir elementai kuriami hierarchine seka: mazgas-kreive-regionas. Pirmasis mazgu rinkinys yra sukuriamas iš mazgų esančį kreivių galuose. Mazgai yra generuojami išilgai sių kreiviu, skaidant jas i kraštinius segmentus. Vèliau mazgai ir elementai generuojami kiekvienoje individualioje srities dalyje, o visas generavimo procesas yra užbaigiamas sujungiant $\mathfrak{i}$ visumą visų srities dalių tinklus.

2. Plintančio fronto technika. Sukurta ekspertinè sistema, kuri nestruktūriniams tinklams generuoti taiko pastaruoju metu labiausiai paplitusią plintančio fronto technika. Pagrindinè jos idèja - vienu metu prie BE tinklo pridedamas vienas elementas. Visas algoritmas gali būti reziumuotas:

2.1. Apibrèžiama sritis, kuri turi būti padengiama $\mathrm{BE}$ tinklu. Tam yra naudojami kraštiniai mazgai, juos jungiančios kraštinès briaunos bei iš šiu briaunu sudaromi regionai.

2.2. Pateikiamos kuriamų elementų dydžių, ištempimo mastelių ir krypcių charakteristikos.

2.3. Naudojantis informacija apie elementu dydžio ir formos pasiskirstyma, yra sudalijamos kraštinès briaunos i fragmentus, kuriu pagrindu yra kuriami naujieji elementai. Būtent še briaunų fragmentai ir sudaro pradini fronta.

2.4. Sritis yra diskretizuojama $\mathfrak{i}$ trikampius elementus, kurie yra kuriami pagrindinès briaunos pagrindu (paprastai yra parenkama mažiausia fronto briauna).

2.5. Parenkama kita briauna, kuri turi būti pašalinta iš fronto; siekiant išvengti didelių elementų fronto susikirtimo su mažų elementu frontu, kita is sąrašo Salinama briauna yra parenkama ta, kuri suformuoja mažiausią elementa.

2.6. Kiekvienai šalinamai briaunai:

2.6.1. Apibrèžiama idealaus mazgo padètis taip, kad gauto elemento forma būtų artima lygiakrašciam trikampiui.
2.6.2. Patikrinama, ar nors vienas kaimynystejje esantis mazgas galetu büti panaudotas naujajam elementui suformuoti. Jei toks mazgas yra, tai jis užfiksuojamas kaip kandidatas ir paieška tęsiama toliau.

2.6.3. Patikrinama, ar elementai, suformuoti su minètais mazgais, nekerta jau sugeneruoty elementu. Jei kerta, tai pasirenkamas kitas mazgas ir vèl bandoma.

2.7. Naujai sugeneruoti mazgai, briaunos ir elementai itraukiami i jų duomenų sąrašus.

2.8. Is foninio tinklo mazgy informacijos ir duomenu saltinių nustatomi reikiami generavimo parametrai.

2.9. Pašalinamos briaunos, kurios daugiau nepriklauso frontui.

2.10. Prie fronto pridedamos naujosios briaunos.

2.11. Jei frontas nèra tušcias, pereinama prie 2.5 punkto, priešingu atveju užbaigiama.

Didžiausias šios technikos privalumas yra tas, kad jis apima ivairias laisvos formos geometrines sritis. Kraštu integruotumas yra garantuotas, nes jų diskretizavimas yra apibrežtas pradinių sąlygu. Didžiausias šios technikos trūkumas yra tas, kad ji netinka neiškilosioms sritims padengti BE tinklu. Dažnai elementụ forma turi būti patobulinama poprocesorinéje dalyje.

3. Elementu parametru funkcijos apibüdinimas foniniu tinklu. Siekiant sugeneruoti BE tinklą su elementu dydžiais tokios eilès, kokios reikia vartotojui, reikia turèti sklandžią funkciją kuri apimtų visą nagrinejjamą sriti. Tam yra naudojamas foninis tinklas, kurio mazguose yra duotos šios funkcijos reikšmès.

4. Tinklo pakeitimo principas. Kartais BE analizei naudinga vietoj reto trikampiu elementy tinklo naudoti retą keturkampių elementų tinklą. Nors dažniausiai yra imanoma generuoti retą keturkampių elementų tinklą tiesiogiai, kartais naudingiau ir paprasčiau pakeisti esamq trikampių elementų tinklą i retą keturkampių elementų tinklą.

\section{Pradinio BE tinklo generavimo ekspertinè sistema}

Per pastaraji dešimtmeti buvo sukurti keli skirtingo automatizacijos lygio BE tinklu generavimo algoritmai [7], kurie dažniausiai ivertina tik objekto geometrinę forma, bet neivertina kraštiniu salygų ir apkrovimo, generuodami pradinị tinklą. Tai reiškia, kad šie generatoriai 
pradeda procesą nuo reto tinklo, kartu padaugeja klaidu̧ todèl reikia daugiau adaptyviosios analizès žingsnių, siekiant konverguoti prie reikiamo tikslumo (1 pav. I kryptis). Kitaip sakant, šiam procesui reikia daugiau laiko, jis yra brangus. Siūloma ekspertiné sistema, skirta pradiniam inžinerinès sistemos BE tinklui generuoti. Tam pasinaudojus informacija apie objekto geometrija, medžiagos charakteristiku pasiskirstyma, kraštines sąlygas ir apkrovimą yra a priori (prieš startuojant $\mathrm{BE}$ analizei) sukuriamas tinklas, kuris gali būti patobulintas ties kritiniais nagrinejamos srities regionais (singuliariais taškais, kampais, dideles itempimu koncentracijos vietose ir kt.). Tikimasi, kad pasiülytas būdas, kuris pradeda sprendimo procesa su beveik optimaliu pradiniu tinklu, darys mažesnes ir tolygiau pasiskirsčiusias klaidas, palyginti su tradiciniu prisitaikanciosios analizès būdu. Todel sprendinys turètų konverguoti su reikiamu tikslumu greiciau, esant mažesnéms laiko sąnaudoms ir mažesnei kainai (1 pav. II kryptis).

Siūloma tokia ,juodosios déžès" tipo ekspertinè sistema, kuri identifikuoja kritinius regionus, kuriuose tinklas turi bũti patobulintas, ir parenka tinkamus tinklo parametrus. Pagrindiniai sio tipo ekspertinių sistemı̨ kūrimo principai pateikti [12]

Śioje ekspertinèje sistemoje žinios yra pateikiamos kaip našumo taisyklès. Šios taisyklès panaudoja IF THEN tipo struktūras taisyklès vykdymui reguliuoti.
„Juodosios dèžès“ ekspertinès sistemos blokinè schema pateikta 2 paveiksle.

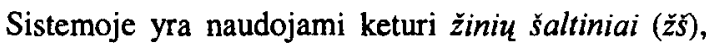
kurie leidžia reguliuoti tinklu perdalijimo procesa. Naudojamu žš funkcijos yra šios:

- Kritinio regiono žš nusistato kritinius taškus (pvz., plyšius, kiaurymes, defektus ar kitus geometrinius netobulumus), kuriuose gali atsirasti ženklūs ittempimų gradientai.

- Kraštiniu sąlygu žs̆ atpažista ivairių rūšiu kraštines sąlygas ir apkrovimą kritiniams taškams identifikuoti.

- Standartinio atvejo žšs sudalija sriti i keletą smulkesnių sricių ir leidžia aproksimuoti ịtempimų skaičiavimą kiekvienos smulkesnès srities kritiniuose taškuose.

- Plitimo banga žš paskirsto BE tinklo elementu dydžius kiekviename kritiniame regione nuo mažiausio iki didžiausio tam tikromis bangomis.

Žiniu šaltiniai išdèstomi pagal eiliškumą. Kontroleris pasirenka žš vykdymui iš eilès. Žiniu šaltiniu išdèstymo tvarka bei kritinių tašku prioritetas yra visiškai nusakomas ekspertinés sistemos rezultatu. Mazgai ir elementai yra sukuriami taikant plintancio fronto metoda, kuris aprašytas 2 šio darbo skyrelyje. Reikia konstatuoti, kad pasiūlyta ekspertinè sistema leidžia sumažinti kompiuterines sanaudas, nes labai greitai sukuriamas optimalus tinklas.

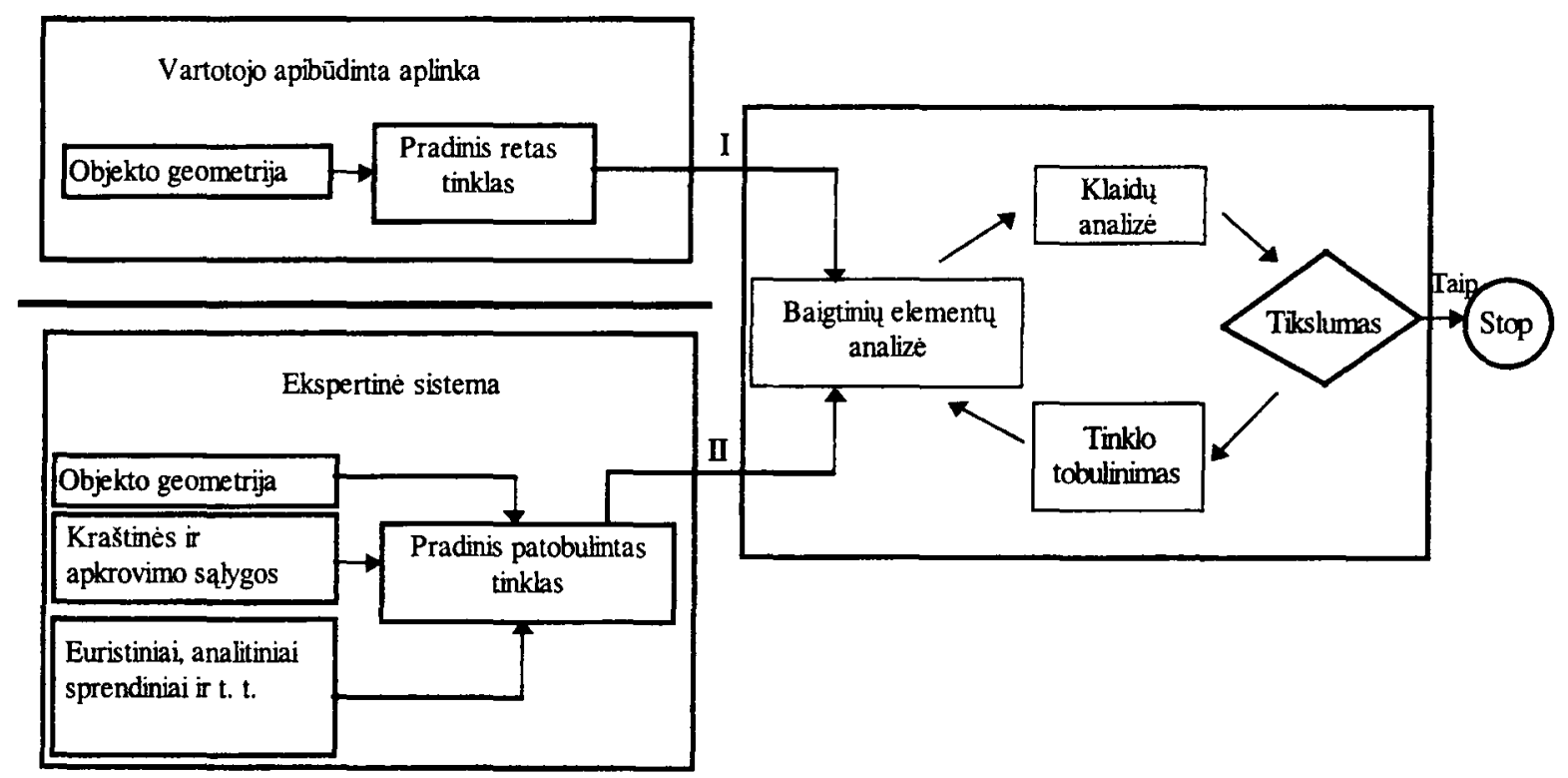

1 pav. PrisitaikanCiosios baigtinį̧ elementų analizès: tradicinio būdo (l kryptis) ir pasiūlyto būdo (II kryptis) blokinè schema

Fig 1. Schematic diagram of the traditional approach (path I) and the suggested approach (path II) to the adaptive finite element analysis 


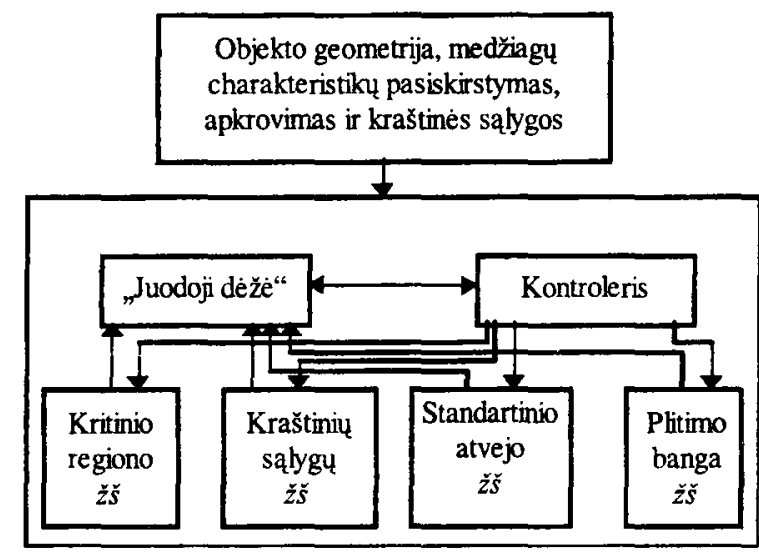

2 pav. „Juodosios dèžès" sistemos blokinè schema

Fig 2. Schematic diagram of the black box system

Žinių bazei atnaujinti reikètụ pridèti papildomas taisykles, apibréžiančias naujai pridedamus žiniu šaltinius.

Kritiniu regionu išrinkimas. Nuskaiciusi visą reikiamą informaciją apie nagrinèjamos srities geometrija. kraštines sąlygas, apkrovima, medžiagos pasiskirstyma, ekspertinè sistema pradeda galimy kritinių regionı (tašku) nustatymą. Kritiniais regionais gali büti ivvairüs geometriniai netobulumai (kiaurymès, plyšiai, singuliarūs taškai, objekto kampai ar apkrauti bei itvirtinti kraštai). Juose paprastai yra dideli itempimu gradientai. Automatinị kritinių regionı̨ išrinkimą atlieka kritinio regiono žs.

Vèliau, kai jau visi galimi kritiniai regionai yra identifikuoti, kraštinių salygy žš išrenka tik tuos galimus kritinius taškus, kurie yra „tikrai“ kritiniai. Tam tikras taskas A vadinamas „tikrai“ kritiniu, jei jame dèl tam tikro poveikio atsiranda ittempimu koncentracija.

Srities sudalïimas. „Juodosios dèžès“ tipo ekspertiné sistema, ivertinusi esamas kraštines salygas, sudalija nagrinejamą sriti i keletą smulkesniu daliu̧, vadinamy standartiniais atvejais, kurioms gali būti atlikta nagrinèjamu dydžiu (pvz., itempimu) aproksimacija. Šis skaiciavimas yra daug paprastesnis, nes paprastesnei sriciai gali bũti žinomi tam tikri analitiniai arba euristiniai sprendiniai.

Pavyzdžiui, ekspertinè sistema, nustačiusi, kad nagrinejjama sritis yra sudaryta iš kelių skirtingų medžiagu, sudalija ją $i$ dalis, kiekvienoje iš kuriụ yra tik viena tam tikra medžiaga. Vèlesniu etapu bus generuojamas BE tinklas kiekvienoje iš sių daliu̧ derinant elementu parametrus šių srixių sąlycio zonoje.

Esant tam tikroms sritims su itempimų koncentratoriais, visų pirma randama tokia standartinè sritis, kuriai

yra žinomas analitinis itempimı sprendinys. Tikrieji itempimai koncentratoriaus aplinkoje yra gaunami dauginant nominalų ịtempimą is tam tikrų pataisos bei koncentracijos koeficientu.

\section{Skaitiniai pavyzdžiai}

Pateikiami dviejų inžinerinių struktūru BE tinklai, kai yra žinoma skirtinga informacija apie inžinerinę sistema. Pasiūlyta ekspertinè sistema, ivertinusi geometrija, galimą apkrovimą bei medžiagos pasiskirstymą, gali valdyti tam tikram uždaviniui spręsti tinkamų tinklu generavimą. Visi pateikiami tinklai yra pirmojo artejimo reti tinklai, kuriuose vèliau galima būtų pakoreguoti elementu dydžius pagal nežinomuju (pvz., ittempimu) pasiskirstymą taikant tinklų adaptyvumo algoritma. Pirmoji inžinerinè struktūra yra sudaryta iš dvieju suglausty sričį (3 pav. a), kurios yra imamos kaip keliy skirtingy medžiagu atitikmenys.

a)

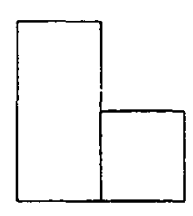

3 pav. Pirmoji inžinerinè struktūra, kai juvertinama: a) tik skirtingos medžiagos; b) ir c) skirtingos medžiagos ir apkrova

Fig 3. The first structure, when evaluated: a) only different materials; b) and c) different materials and loading

Pirmosios inžinerinès struktūros BE tinklai yra pateikti 4-6 paveiksluose. 4 paveiksle pateikiamas tinklas, kai ekspertinè sistema îvertino tik skirtingas medžiagas (3 pav. a) skirtingose struktūros dalyse. Šj tinklą sudaro 889 mazgai ir 1697 elementai.

5 pav. pateiktas tinklas, kai ekspertinè sistema ivertino skirtingas medžiagas ir tokią apkrovą, kaip parodyta 3 paveikslo b dalyje. Š tinkla sudaro 1072 mazgai ir 2045 elementai.

6 pav. pateikiamas tinklas, kai ekspertinè sistema jvertino skirtingas medžiagas ir tokią apkrova, kaip parodyta 3 paveikslo c dalyje. Si tinklą sudaro 1210 mazgu ir 2303 elementai.

Šiais pavyzdžiais iliustruojamos tinklų sudètingoms inžinerinèms struktūroms generavimo galimybès. Is 4,5 , 6 pav. matyti, jog galima gana lengvai, taikant siūloma 
ekspertinę sistemą ir turint elementariają pradinę informacija, generuoti skirtingus $\mathrm{BE}$ tinklus priklausomai nuo projektuotojo poreikiu.

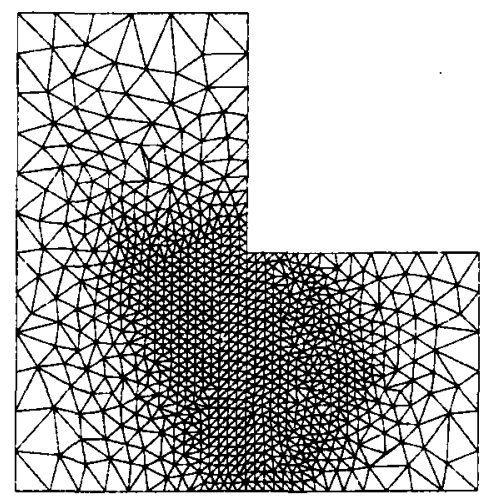

4 pav. Pirmosios inžinerinès struktūros I tinklas Fig 4. The first mesh of the first structure

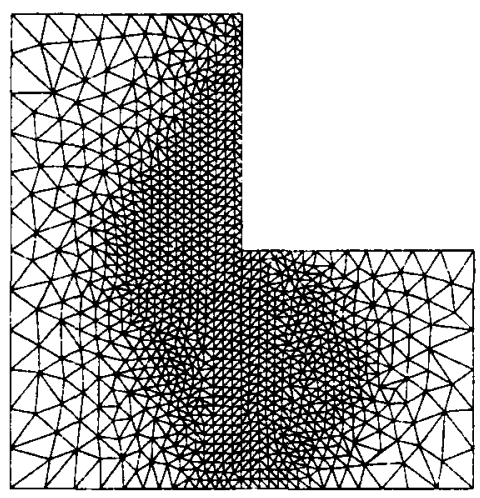

5 pav. Pirmosios inžinerinès struktũros II tinklas Fig 5. The second mesh of the first structure

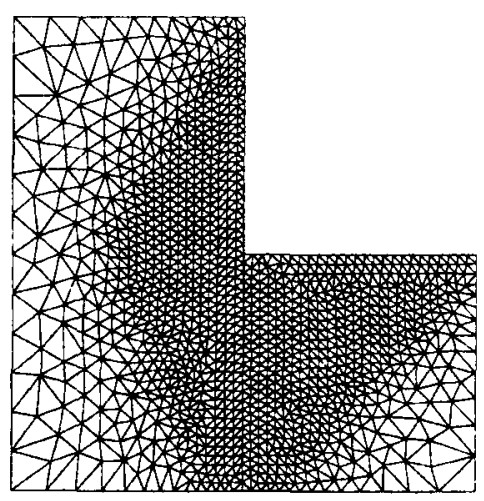

6 pav. Pirmosios inžinerinès struktūros III tinklas Fig 6. The third mesh of the first structure
Antroji inžinerinè struktūra yra sudaryta iš triju suglaustu sričiu, kurios imamos kaip keliu skirtingu medžiagų atitikmenys ( 7 pav. a). a)

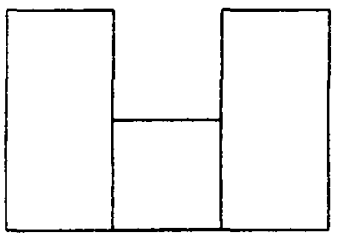

b)

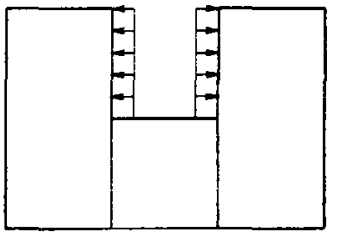

7 pav. Antroji inžinerinè struktūra, kai juertinama: a) tik skirtingos medžiagos; b) skirtingos medžiagos ir apkrova

Fig 7. The second structure, when evaluated: a) only different materials; b) different materials and loading

Antrosios inžinerinès struktūros BE tinklai yra pateikti 8-11 paveiksluose. 8 pav. pateikiamas tinklas, kai ekspertinè sistema ivertino skirtingas medžiagas ir tokią apkrova, kaip parodyta 7 paveikslo b dalyje. Šj tinkla sudaro 1675 mazgai ir 3190 elementu.

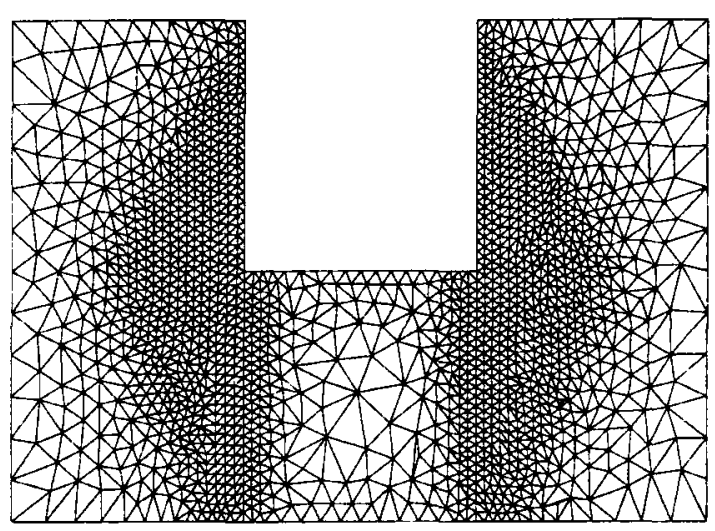

8 pav. Antrosios inžinerinès struktūros I tinklas

Fig 8. The first mesh of the second structure

9 pav. pateiktą tinklą sudaro 912 mazgy ir 1696 elementai.

8 ir 9 pav. tarpusavyje skiriasi tik tuo, kad 9 pav. pateikto tinklo smulkūs elementai yra 1,5 karto didesni nei 8 paveiksle pateikto tinklo. Todèl pakeiciama tik vienos konstantos reikšmè.

10 pav. pateikiamas tinklas, kai ekspertinè sistema ivertino tiktai skirtingas medžiagas ( 7 pav. a) skirtingose struktūros dalyse. Šj tinklą sudaro 1305 mazgai ir 2486 elementai. 


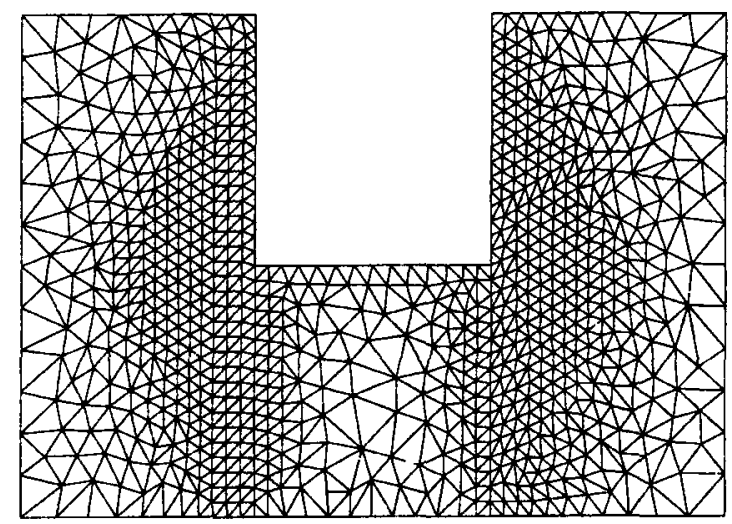

9 pav. Antrosios inžinerinès struktūros II tinklas

Fig 9. The second mesh of the second structure

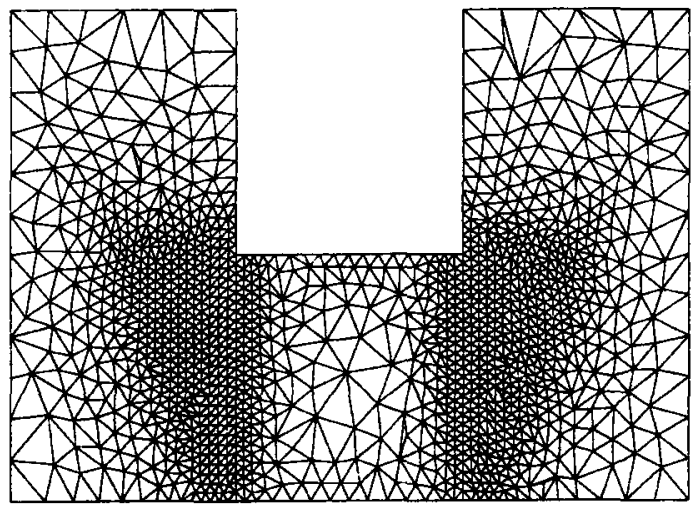

10 pav. Antrosios inżinerinès struktūros III tinklas

Fig 10. The third mesh of the second structure

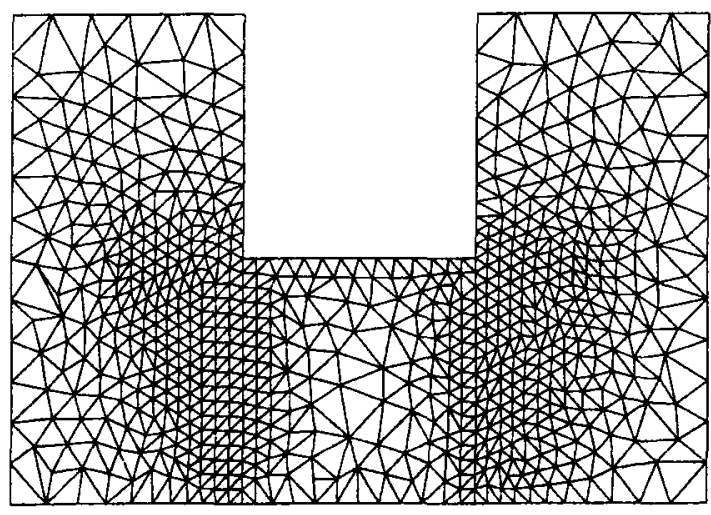

11 pav. Antrosios inžinerinès struktūros IV tinklas

Fig 11. The fourth mesh of the second structure
11 pav. pateiktą tinklą sudaro 745 mazgai ir 1382 elementai. 11 pav. pateikto tinklo smulkūs elementai yra 1,5 karto didesni nei 10 pav. pateikto tinklo.

Kaip matyti iš pateiktų tinklu, sričiu sandüroje gaunami suderinti tinklai.

Šio darbo tikslas būtent ir buvo parodyti, kad taikant pasiūlytą ekspertinę sistemą bus galima sugeneruoti suderintus tinklus. Visi 4-6 ir 8-11 pav. pateikti BE tinklai yra viso labo pirminiai tinklai, kuriu panaudojimas neduoty sprendinių su visiškai vienodai pasiskirsčiusia skaitinès diskretizacijos paklaida, bet ju panaudojimas leidžia sumažinti iteracijų skaixių, norint sukurti optimalu tinklą. Jais siekiama iliustruoti skirtingy BE tinkly sudètingoms struktūroms generavimo galimybes, atsižvelgiant i projektuotojo poreikius, jo patirti ir pan.

Šie tinklai yra sugeneruoti neatliekant jokių tinklo patobulinimo procedūry, tokių kaip tinklo glodinimas, briauny sukeitimas vietomis, juose nedaug netobulos formos elementu, o tai reiškia, kad, taikant plintančio fronto metoda, yra generuojami tinklai, sudaryti is pakankamai tobulos formos elementu, o tai vèliau daro jtaka skaitinès analizès tikslumui.

\section{Išvados}

Šiame darbe yra nagrinèjamas nestruktūrinių baigtiniu elementų tinklu generavimas, taikant plintancio fronto technika. Daugiausia dèmesio skiriama inžineriniu struktūrų sudarytų is kelių suglaustų sricių suderintiems tinklams generuoti. Pateikiama originali ekspertinè ,juodosios dèžès" tipo sistema, kuri leidžia generuoti skirtingus pradinius BE tinklus priklausomai nuo pradinès inžinerinès sistemos informacijos. Atlikus keletą skaitiniu eksperimenty galima teigti, kad galima būtu generuoti îvairių sudètingos geometrijos struktūry tinklus.

Tinkly generavimas dvimatems konstrukcijoms yra tik pirminis pasiūlytos sistemos realizavimo žingsnis, vèliau numatoma ją pritaikyti ir trimaciams uždaviniams.

Pastaruoju metu plačiai nagrinèjama plintancio fronto metodo realizacija lygiagreciaisiais procesoriais [8, 10, 11], ypac kai generuojami erdviniu elementu tinklai, sudaryti iš šimtu tūkstancių ar net keliu milijonų elementu. Pasiūlyta sudetingy inžineriniu struktüru tinklu generavimo ekspertinè sistema gali büti sèkmingai naudojama realizuojant ja lygiagrečiaisiais procesoriais. Ši sistema yra sukurta taip, kad leidžia minimizuoti procesoriu tarpusavio komunikavimo sąnaudas, kartu labai padi- 
deja algoritmo efektyvumas. Sèkmingas realizavimas užtikrinamas todèl, kad diskretizuojama inžinerinè struktūra jau duomenų faile yra dalijama $\mathfrak{i}$ atskiras sritis, kuriose galetų tinklą genenoti atskiri procesoriai, pradiniame etape gavę iš vieno procesoriaus, kuris dažniausiai vadinamas „కeimininku“, informaciją apie bendru briaunu sudalijimą. Tolesniame etape, pačiame imliausiame skaiciavimo sąnaudų požiūriu, kiekvienas procesorius generuoja jam paskirtos atskiros srities BE tinklą nekomunikuodamas su kitais procesoriais. Vèliau „Šeimininkas“, surinkęs iš kitu procesoriu - „tarnų“ informacija apie visas sugeneruotas sritis, turèty sujungti jas i visuma, patikrindamas, kaip suderinti mazgai bendrose briaunose.

\section{Literatura}

1. J. Frykestig. Advancing front mesh generation techniques with application to the finite element method. Chalmers University of Technology. Göteborg, 1994. $224 \mathrm{p}$.

2. R. Vilsmeier, D. Hănel. Adaptive methods on unstructured grids for Euler and Navier - Stokes equations // Computer Fluids. Vol 22, No 4/5, 1993, p. 485-499.

3. M. J. Marchant, N. P. Weatherill. Unstructured Grid Generation for Viscous Flow Simulations // Proc. of the VI-th conference on Numerical Grid Generation in Computational Fluid Dynamics (eds. Eisemann, P. R. et. al.). Swansea, 1994, p. 151-162.

4. S. Lopez, R. Casciaro. Algorithmic Aspects of Adaptive Multigrid Finite Element Analysis // J. Numerical Methods in Engineering, 1997, V. 40, p. 919-936.

5. D. J. Mavriplis. Mesh generation and adaptivity for complex geometries and flows // Handbook of computational fluid mechanics. Academic Press, 1996, p. 417-455.

6. P. L. George, E. Seveno. The Advancing - Front Mesh Generation Method revisited // J. Numerical Methods in Engineering, 1994, V. 37, p. 3605-3619.

7. S. H. Lo. Delaunay Triangulation of Non-Convex Planar Domains // J. Numerical Methods in Engineering, 1989, V. 28, p. 2695-2707.

8. J. K. Wilson, B. H. V. Topping. Parallel adaptive tetrahedral mesh generation by the advancing front technique // Computers and structures, 1998, V. 68, p. 57-78.

9. R. Lohner. Progress in Grid Generation via the Advancing Front Technique // Engineering with Computers, 1996, V 12 , p. $186-210$.

10. B. H. V. Topping, B. Cheng. Parallel quadrilateral mesh generation // Advances in Computational Structures Technology (ed. B.H.V.Topping). Civil-Comp Press, Edinburgh, 1996, p. 297-313.

11. J. Sziveri, B. Cheng, A. Bahreininejad, J. Cai, G. Thierauf, B. H. V. Topping. Parallel quadrilateral subdomain generation // Advances in Computational Structures Technology (ed. B. H. V. Topping). Civil-Comp Press, Edinburgh, 1996, p. 313-325.

12. E. Kang, K. Haghighi. Inteligent Finite Element Mesh Generation // Engineering with Computers, 1995, V. 11, p. 7082.
Iteikta 19990521

\section{GENERATION OF THE UNSTRUCTURED FE-GRIDS FOR COMPLEX 2D OBJECTS}

\section{E. Stupak, R. Baušys}

Summary

For the numerical simulation of engineering problems, the finite element method (FEM) is among the most popular approaches. One of the main concerns in a finite element analysis is the adequacy of the finite element grid. The accuracy of the FEM depends on the size, shape and placement of the elements. On the other hand, the total computational cost is determined by the total number of elements in FE model. An increased accuracy can be obtained by the global reduction of the element size, but this can be characterised by drastically increased computational cost. Thus, in many engineering applications it is desirable to generate not regular FE mesh with finer grid in the regions where accuracy of numerical simulation is of most importance and with more coarse grid in the other regions.

In this paper we present a new approach to the grid generation of the multimaterial or multidomain engineering systems by the advancing front technique. This technique has proved successful in generating unstructured meshes in two and three dimensions [1-9]. The algorithm of the technique is summarised in section 2. Common for all approaches of advancing front mesh generation is that the generation problem is divided into three parts. First, the specification of the mesh size attributes, second, the discretisation of the boundaries, and, third, the discretisation of the interior of the domain. In the advancing front technique the front is defined as the boundary between the gridded and ungridded region. The key algorithmic step that must be addressed to advancing front methods is the proper introduction of new elements into the ungridded region. For triangular and tetrahedral grids the elements are introduced sequentially one at a time. The most obvious advantage of the advancing front method is that it directly incorporates free form geometry.

Direct implementation of the advancing front technique for multimaterial or multidomain engineering applications is still challenging. Grid generation in the place of few materials or domain contact must ensure the compatibility of nodes on common boundary segments (nodes on common boundary segments must be in the same positions). The advancing front technique does not include non-convex domain, so at the first step non-convex domain of discretisation is decomposed into few convex subdomains. The subdomain of interest must be defined by describing a course background mesh of triangle elements, covering the entire multidomain region, which forms the input for finite element analysis.

In this work, a black box architecture expert system has been developed which incorporates the information about the object geometry as well as the boundary and loading conditions, distribution of materials characteristics to generate an a priori (before the finite element analysis is carried out) mesh which is more refined around the critical regions (singularities, re-entrant corners, regions with high-stress concentration, etc) of the problem domain. This system uses a new concept of subtracting to locate the critical regions in the domain and to assign priority and mesh size to them. This involves the decomposition of the original structure into substructures (or primitives) for which an initial and approximate analysis can be performed by using analytical solutions and heuristics. When incorporated into and compared with the traditional approach to the adaptive finite element analysis, it is expected that the proposed approach. which starts the process with near optimal meshes, will be more accurate and efficient. 
Several numerical examples are presented and discussed. Examples demonstrate that our approach enables to generate the compatible meshes for multimaterial or multidomain problems. The quality of meshes is good, there are no ill-shaped elements. By the proposed expert system we can generate the mesh for any complex structure. The generation of $2 \mathrm{D}$ meshes is only the first step using the proposed expert system; in future we shall extend it for 3D meshes.

During the last decade a lot of research has been devoted to extension of the advancing front technique to the parallel computers $[8,10,11]$. But the application of the technique to parallel processors is still challenging. In fact, we have to solve how to minimise inter-processor communication during mesh generation of subdomains. The proposed expert system for complex structures grid generation enables to use it with paral. lel computers. At the first step the domain of discretisation is decomposed into subdomains and all the surfaces defining the boundaries of subdomains to be gridded are triangulated. Later all subdomains can be meshed concurrently and no more interprocessor communication is required. The master task sends to workers tasks information about dividing common boundaries and information of each subdomain. The workers tasks receive their subdomain data and mesh their subdomain. Later the master receives the information from the workers tasks and joins gridded subdomains to one structure, ensuring the compatibility of nodes on common boundaries. So this suggested expert system enables to minimise the communications and costs of computations. The implementation of the expert system to parallel processors is to be done in the future.

Eugeniuš STUPAK. MSc, Research Assistant. Vilnius Gediminas Technical University, Laboratory of Numerical Modelling. Saulètekio al. 11, 2040 Vilnius, Lithuania.

A graduate of Vilnius Gediminas Technical University, Civil Engineering Faculty (1997). Since 1997 assistant at the Dept of Strength of Materials. Research interests: computational mechanics, adaptive finite element strategies in statics.

Romualdas BAUSYS. Doctor, Senior Researcher, Associate Professor. Vilnius Gediminas Technical University, Laboratory of Numerical Modelling. Sauletekio al. 11, 2040 Vilnius, Lithuania.

$\mathrm{PhD}$ (1989). Common research with scientists from Chalmers University of Technology (Göteborg, Sweden). Research interests: error estimation and adaptive finite element strategies in statics and dynamics, optimisation and analysis procedures for non-linear problems. 